\title{
Ice physical properties, structural characteristics and stratigraphy in Hobson's Choice Ice Island and implications for the growth history of East Ward Hunt Ice Shelf, Canadian High Arctic
}

\author{
MARTIN O. JeFFriEs, \\ Geophysical Institute, University of Alaska Fairbanks, Fairbanks, Alaska 99775-0800, U.S.A. \\ HAROLD V. SERSON, \\ 977 Stellyscross Road, Brentwood Bay, British Columbia VOS 1A0, Canada \\ H. Roy KROUSE, \\ Department of Physics, University of Calgary, Calgary, Alberta T2N 1N4, Canada \\ William M. SACKINGER \\ Geophysical Institute, University of Alaska Fairbanks, Fairbanks, Alaska 99775-0800, U.S.A.
}

\begin{abstract}
Hobson's Choice Ice Island is a tabular iceberg that calved in 198283 from East Ward Hunt Ice Shelf, N.W.T., Canada. Four ice cores have been analyzed for ice-crystal size, structure and fabric, bulk density, liquid electrical conductivity, $\delta^{18} \mathrm{O}$ and tritium. This has enabled a complete characterization of the physical properties and the structural characteristics of the ice-shelf component of Hobson's Choice Ice Island and the first ever study of the stratigraphy and growth history of East Ward Hunt Ice Shelf. The $\delta^{18} \mathrm{O}$ values range from -34.6 to $-24.1 \%$ and indicate that all the ice is derived directly and/or indirectly from precipitation. High tritium values occur only in the lowermost $5 \mathrm{~m}$ of the ice shelf in a layer named stratum B. The tritium is anthropogenic and indicates bottom accretion of fresh-water ice since 1952, most likely from fresh water flowing out of Disraeli Fiord below the eastern ice shelf. Above this deepest and youngest ice layer is a $35-38 \mathrm{~m}$ thick, unconformable layer (stratum A) comprising three ice types: iced-firn, slush ice and lake ice. This depositional-superimposed ice represents past surface accumulation, which, according to $\delta^{18} \mathrm{O}$ and ice-crystal structure and size variations, occurred in three major periods, each interrupted by major ablation periods. Fresh water flowing out of Disraeli Fiord below the ice shelf during those warm intervals was the most likely agent responsible for the ablation and eventual complete loss of the original seaice platform on which stratum A initially accumulated. The three sub-strata of stratum A vary in thickness from core to core and suggest that there has been an inversion of relief during each ablation period. The different properties and occurrences of the three superimposed ice types are due primarily to past topographic variability.
\end{abstract}

\section{INTRODUGTION}

Ice shelves are floating ice masses of considerable horizontal extent attached to the coast. They are substantially thick, generally showing $\geqslant 2 \mathrm{~m}$ a.s.l., have level or gently undulating surfaces and rise and fall with the tide, except where they are grounded on the sea floor. The only ice shelves in North America, and probably the most extensive ice shelves in the entire north polar region, are those located along the northern coast of Ellesmere
Island in the Canadian High Arctic adjacent to the Arctic Ocean (Fig. 1).

The origin and subsequent growth of the Ellesmere Island ice shelves can be divided into primary and secondary mechanisms. The primary mechanisms are: the seaward extension of grounded glaciers to form glacier tongues; and, the growth of thick sea ice, which remains landfast for many years (Koenig and others, 1952; Jeffries, 1987). Lemmen and others (1988a) have proposed the genetic terms "glacial shelf ice" and "sea-ice ice shelf" 


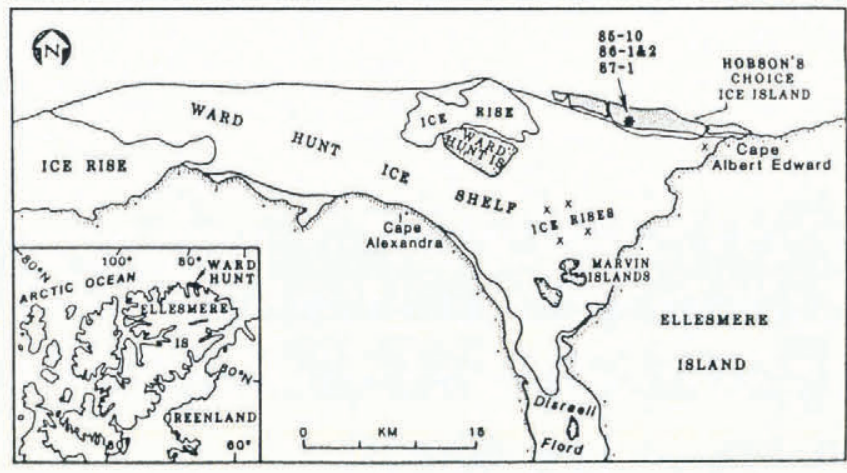

Fig. 1. Map of Ward Hunt Ice Shelf and the location and extent of the ice-island calving that occurred in 1982-83. The approximate ice-shelf location of the Hobson's Choice Ice Island ice cores is marked.

respectively for ice shelves originating by these mechanisms. Since one part of an ice shelf may have originated as glacial ice and another part as sea ice, the term "composite ice shelf" may be appropriate in some circumstances (Lemmen and others, 1988b). The secondary mechanisms are: accumulation of snow on the upper surface of the glacier tongues and the landfast sea ice; and, bottom accretion of fresh, brackish and sea ice from fresh, brackish and sea water flowing below the glacier tongues and the landfast sea ice (Jeffries, 1987).

There has been interest in the Ellesmere Island ice shelves for 40 years since they were first discovered and identified as the source of ice islands (Koenig and others, 1952). Ice islands are tabular icebergs that periodically calve from the ice shelves and then drift in the Arctic Ocean, often for decades. Because of their stability and longevity as they move around the Arctic Ocean in the Beaufort Gyre and the Transpolar Drift, a number of ice islands have been used as drifting research stations, e.g. T3, ARLIS-II and Hobson's Choice. The drift of ice islands also takes them into the shallow coastal waters of the southern Beaufort Sea off the Yukon Territory and Alaska where they are a potential hazard to offshore petroleum exploration and development.

As a consequence of the numerous possible combinations of primary and secondary growth mechanisms, the Ellesmere Island ice shelves, and thus the ice islands, may be stratigraphically complex, and comprise different ice types, with particular physical properties and structural characteristics which reflect different growth processes and conditions. A knowledge of the physical properties, structural characteristics and stratigraphy of ice islands is valuable for: (1) the safe design and operation of offshore structures, since the deformation and failure of the ice is influenced by those parameters (e.g. Jeffries and others, $1990 \mathrm{a}, \mathrm{b})$; and (2) the elucidation of the origin and growth history of the parent ice shelf (e.g. Crary, 1958; Muguruma and Higuchi, 1963; Smith, 1964). The icecore studies on ice islands T-3 (Crary, 1958; Muguruma and Higuchi, 1963) and ARLIS-II (Smith, 1964) documented the considerable structural-stratigraphic variability that must exist within the Ellesmere Island ice shelves, but unfortunately it was not possible to identify precisely the former locations of those ice islands, i.e. their parent ice shelves.
In 1982-83, a number of ice islands, with a total area of about $40 \mathrm{~km}^{2}$, calved from East Ward Hunt Ice Shelf (Fig. 1) (Jeffries and Serson, 1983). The largest of those ice islands subsequently became known as Hobson's Choice (Fig. 1) and the site of a research station operated by the Polar Continental Shelf Project (Hobson and others, 1989). In 1985-87 we obtained four ice cores from the thickest, ice-shelf component of Hobson's Choice Ice Island for a study of the physical and mechanical properties, structural characteristics and stratigraphy of the ice. In this paper the variations in the physical properties, structural characteristics and stratigraphy of the ice-island ice cores are discussed with particular reference to the growth conditions, processes and history of East Ward Hunt Ice Shelf.

\section{BACKGROUND ON HOBSON'S CHOICE ICE ISLAND-WARD HUNT ICE SHELF}

Ward Hunt Ice Shelf is the largest of the Ellesmere Island ice shelves. Located at the mouth of Disraeli Fiord, the ice shelf presently has an area of about $440 \mathrm{~km}^{2}$ and a thickness of $40-50 \mathrm{~m}$.

Hobson's Choice Ice Island (Fig. 2) and Ward Hunt Ice Shelf have a striking, undulating surface topography of linear hummocks (ridges) and depressions (troughs), commonly called "rolls" (Hattersley-Smith, 1957). On East Ward Hunt Ice Shelf and Hobson's Choice Ice Island the crest-to-crest spacing of the hummocks is typically $200 \mathrm{~m}$ and the depressions are of the order of $2 \mathrm{~m}$ deep. The present ice-shelf surface is an ablation surface where there has been a negative surface mass balance since the early part of this century (Hattersley-Smith and Serson, 1970; Serson, 1979). Today, due to the warm summers and resultant snow and ice melt, shallow lakes occupy the lowest parts of the depressions. In winter, most lakes apparently freeze completely to the underlying ice.

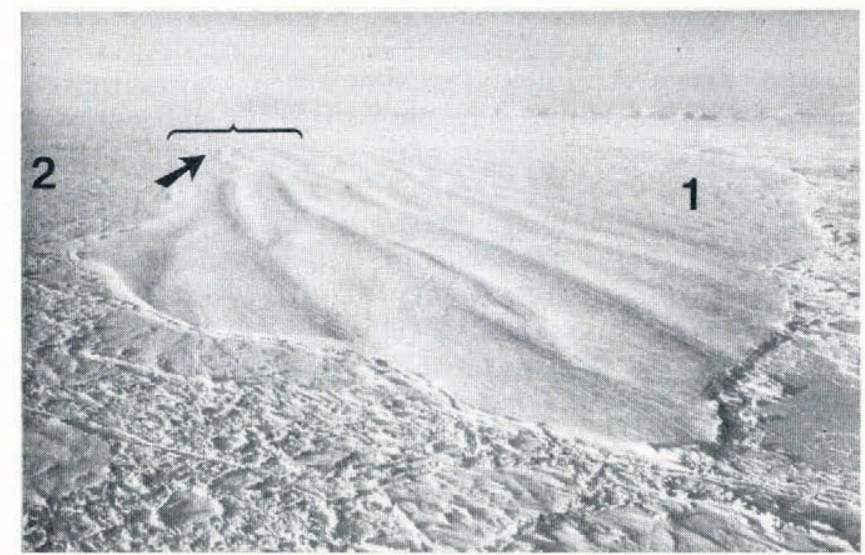

Fig. 2. Oblique aerial photograph of Hobson's Choice Ice Island. The linear depressions and hummocks are clearly visible on the ice-shelf component. Numbers 1 and 2 identify pre-existing multi-year landfast sea ice and incipient multiyear pack-ice components, respectively. The curly bracket lies above the general location of the Polar Continental Shelf Project research station and the sites of the ice cores; the arrow marks the hummock where core 86-1 was obtained. (Photograph by courtesy of Polar Continental Shelf Project.) 
In its position across the mouth of Disraeli Fiord (Fig. 1) the ice shelf acts as a floating dam. Consequently, a layer of low-salinity water, with a depth equivalent to the ice-shelf draft $(\sim 44 \mathrm{~m})$, lies year-round upon deeper sea water (Keys, 1978; Jeffries, in press). Extremely negative $\delta^{18} \mathrm{O}$ values and high levels of tritium in the surface layer are evidence that snow-meltwater run-off from the surrounding land is the main contributor to the freshwater layer (Jeffries, 1985, in press).

Ward Hunt Ice Shelf is a sea-ice ice shelf, which originated about 3000 years ago as multi-year landfast sea ice grew across the mouth of Disraeli Fiord (Crary, 1960). There is no evidence that any part of the ice shelf originated by the seaward advance of grounded glaciers. Massive layers of sea ice and brackish ice, some exceeding $20 \mathrm{~m}$ thick, remain in the ice shelf to the west and south of Ward Hunt Island (Fig. 1) (Lyons and others, 1971; Jeffries and others, 1988; Jeffries and Sackinger, 1989; Jeffries (1991). Some of the brackish and sea ice is undoubtedly hundreds, possibly thousands of years old, yet it contains liquid brine in volumes exceeding those found in the much younger multi-year ice that covers most of the Arctic Ocean today (Jeffries, 1991). The radar energy-attenuating properties of the liquid brine would account for the absence of bottom reflections from those areas of the ice shelf during airborne radio-echo sounding in 1981 (Narod and others, 1988).

Bottom reflections were, however, obtained during radio-echo sounding over large areas of East Ward Hunt Ice Shelf and an ice thickness of $45-50 \mathrm{~m}$ was measured (Narod and others, 1988). The implication that there was no sea ice to attenuate the radar energy in that part of the ice shelf was subsequently corroborated by liquid electrical conductivity and oxygen-isotope $\left(\delta^{18} \mathrm{O}\right)$ analysis of the first, $42 \mathrm{~m}$ core drilled right through the ice-shelf component of Hobson's Choice Ice Island (Jeffries and others, 1988). The absence of sea ice was attributed to the turnover of ice by a process of bottom accretion of freshwater ice accompanied by surface ablation, which, over a 400-500 year period, led to the sea ice melting and running off at the surface (Jeffries and others, 1988).

Since that initial interpretation of the first Hobson's Choice Ice Island ice-core record, we have made observations and measurements of ice-crystal structure, size and fabric in the three subsequent ice cores. On the basis of the new structural data and a re-examination of previous isotopic data, we have revised our interpretation of the stratigraphy, growth conditions, processes and history of East Ward Hunt Ice Shelf.

\section{METHODS}

Ice cores from Hobson's Choice Ice Island were obtained with a PICO (Polar Ice Coring Office) lightweight or similar auger in September 1985 (core 85-10), April-May 1986 (cores 86-1 and 86-2) and May 1987 (core 87-1). Core 85-10 was shared with a third party and only small pieces of ice from regularly spaced intervals along the entire length of the core were made available to us for analysis of SEC (specific electrolytic conductivity or liquid electrical conductivity), ${ }^{18} \mathrm{O} /{ }^{16} \mathrm{O}$ ratios $\left(\delta^{18} \mathrm{O}\right)$ and tritium. The full length of each of cores 86-1 and 86-2

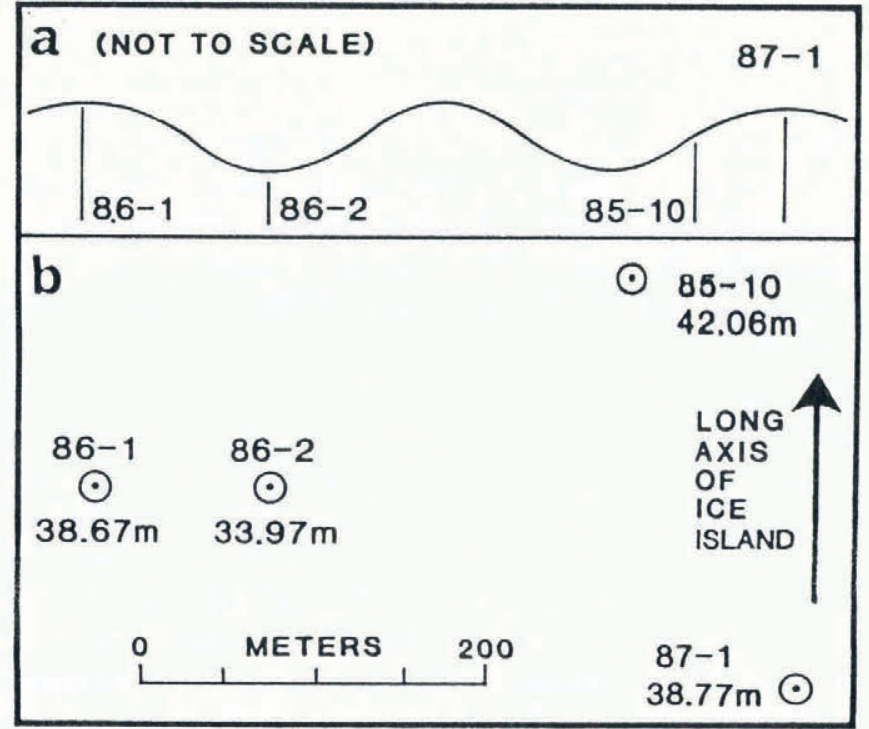

Fig. 3. a. Location of ice cores relative to the undulating topography of hummocks and depressions. On the basis of topographic survey and cross-correlation between cores, the elevation differences of the other cores relative to core 86-1 are $-2.11 \mathrm{~m}$ (core 86-2), $-1.70 \mathrm{~m}$ (core 85-10) and $-0.40 \mathrm{~m}$ (core 87-1).b. Plan view of ice-core locations, including core depths. The minimum distance between cores is $100.6 \mathrm{~m}$ (cores 86-1 and 86-2) and the maximum distance is $432.3 \mathrm{~m}$ (cores 86-1 and 87-1). The cores were obtained within $a$ distance of $750 \mathrm{~m}$ of the edge of the ice island corresponding to the line of fracture at the time of calving, i.e. about $2.4 \mathrm{~km}$ from the former ice-shelf front.

was available for analysis of SEC, $\delta^{18} \mathrm{O}$, tritium, bulk density, and ice-crystal structure, size and fabric. Core 871 was also shared with a third party, but large sections were available for the above analyses.

The length of each core, their topographic locations and positions relative to one another are illustrated in Figure 3. It is important to note that only core $85-10$ was drilled right through the ice island. The other cores were not drilled as deep. Core $86-1$ was drilled at the highest elevation at the crest of the first hummock about $100 \mathrm{~m}$ from the edge of the ice-shelf component (Figs 2 and $3 \mathrm{~b}$ ). All depths in the ice refer to the top surface of core 86-1. Also, all core-data profiles are plotted with reference to the top of core 86-1.

Bulk density of individual core sections was determined by weighing in air on a triple-beam balance and measuring their dimensions with calipers. Using a band saw, horizontal and vertical sections were cut from individual pieces of cores 86-1, 86-2 and 87-1. Vertical thick sections of $1-2 \mathrm{~mm}$ thickness were illuminated in crossed polarizers and photographed for records of gross structural variations. Representative thick sections were then selected and reduced to a thickness of $1 \mathrm{~mm}$ before being photographed in plain light and between crossed polarizers. All horizontal sections were mounted on glass slides and reduced to a thickness of $<0.5 \mathrm{~mm}$ with a handheld microtome blade before being photographed between crossed polarizers.

$c$-axis orientations were determined using a Rigsby stage and the data were plotted on the lower hemisphere 
of a Schmidt net. The mean diameter of all ice crystals in each horizontal section was calculated according to $d=\left(6 / \mathcal{N}_{\mathrm{A}} \pi\right)^{1 / 2}$, where $d$ is the mean ice-crystal diameter (mm) and $\mathcal{N}_{\mathrm{A}}$ is the number of crystals per unit area. All crystals falling across the edge of the measurement area were included; hence, all values of $d$ are slightly underestimated. The adopted ice-texture classes are: fine, 1$5 \mathrm{~mm}$; medium, 5-10 mm; coarse, $10-20 \mathrm{~mm}$; very coarse, $>20 \mathrm{~mm}$.

The ${ }^{18} \mathrm{O} /{ }^{16} \mathrm{O}$ ratios of melted samples were measured using a mass spectrometer. The oxygen-isotopic composition is expressed as $\delta^{18} \mathrm{O}$, the fractional difference in parts per thousand (per mil, \%o) between the isotope-abundance ratio $\left({ }^{18} \mathrm{O} /{ }^{16} \mathrm{O}\right)$ of the unknown sample and a standard (V-SMOW: Vienna-Standard Mean Ocean Water). The tritium activity of melted samples from cores $85-10,86-1$ and $86-2$ was measured by direct liquid scintillation counting without prior enrichment. Tritium activity is expressed in tritium units (TU) where $1 \mathrm{TU}$ represents one tritium atom per $10^{18}$ hydrogen atoms. The SEC of melted samples was measured using a Beckman conductivity meter.

\section{PHYSIGAL PROPERTIES, STRUGTURAL CHARACTERISTICS AND STRATIGRAPHY}

\section{Tritium}

Tritium activity was measured at intervals along the length of cores 85-10, 86-1 and 86-2 (Fig. 4). In cores 86-1

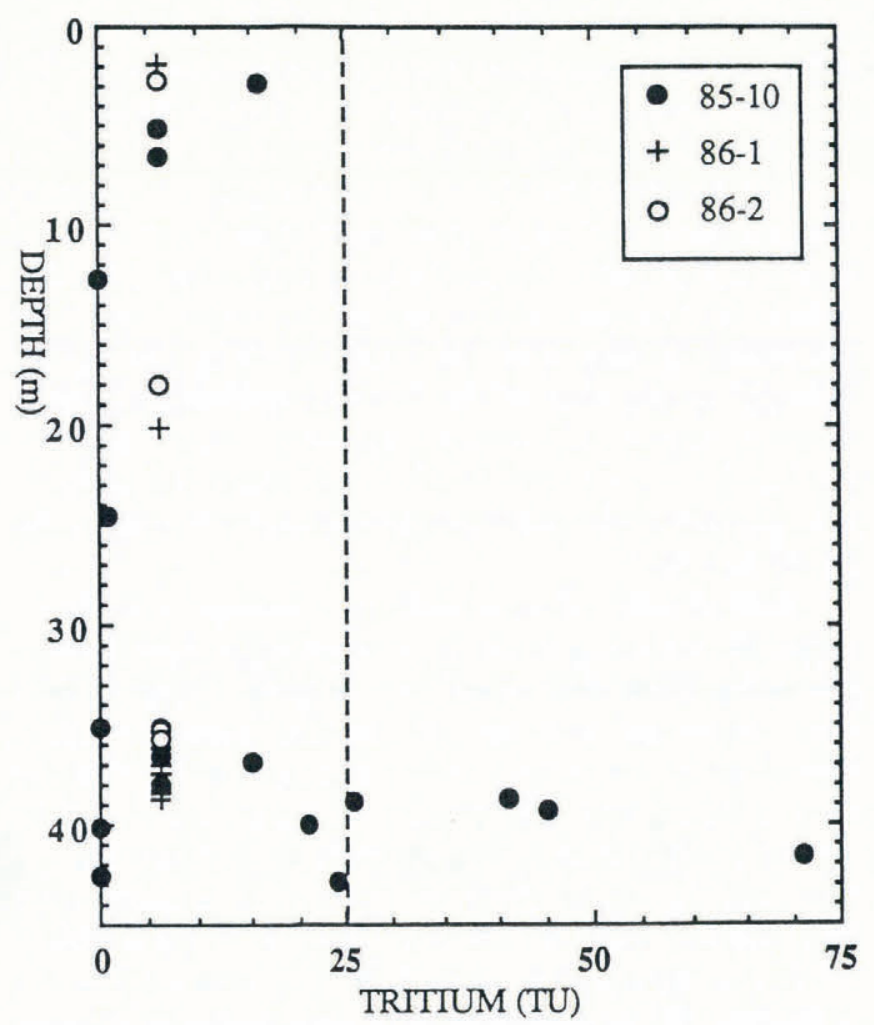

Fig. 4. Tritium activity in cores $85-10,86-1$ and 86-2. Values to the left of the vertical dashed line at $25 \mathrm{TU}$ correspond to those of natural background levels (Gat, 1980). Values to the right of the line are considered to be anthropogenic and, therefore, of recent origin.
OXYGEN-18 (o/\%)

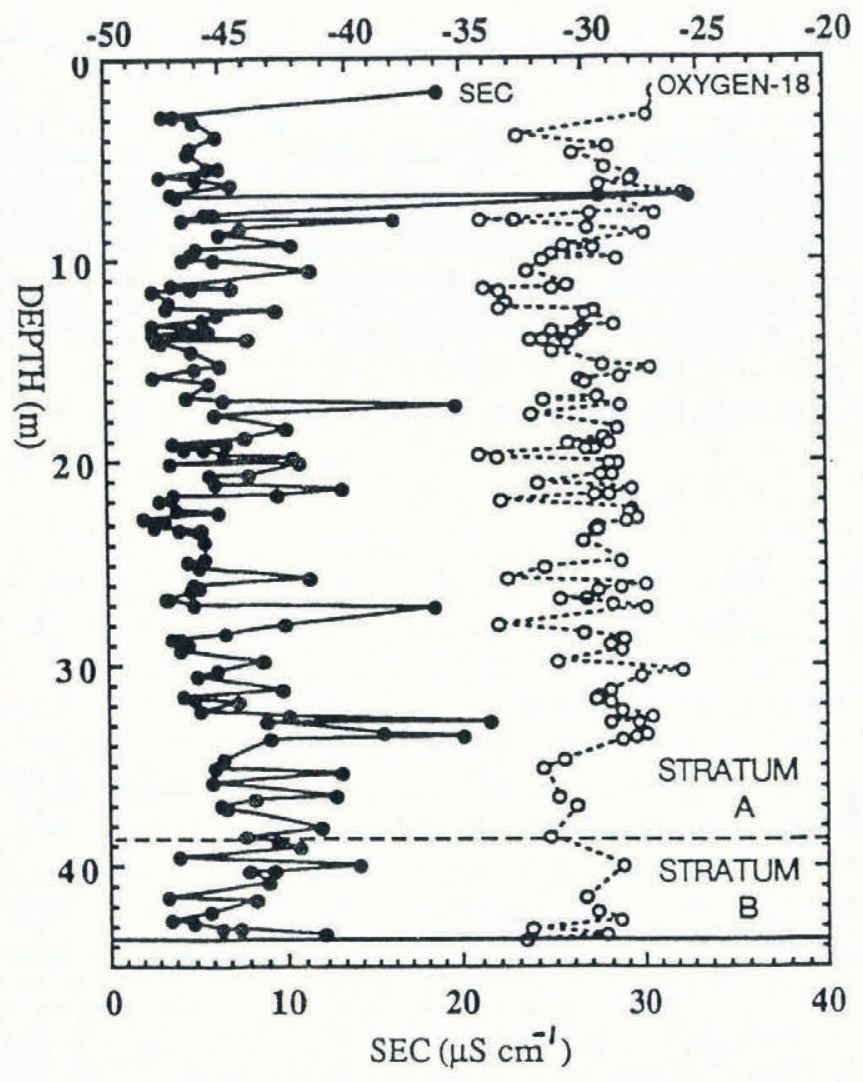

Fig. 5. SEC and $\delta^{18} O$ profiles in core $85-10$. The base of the ice island-ice shelf and lowermost $5 \mathrm{~m}$ of ice where anthropogenic tritium was measured are marked.

and 86-2, the tritium values correspond only to those of the natural background levels. Similar values occur at equivalent depths in core 85-10. Below $38.70 \mathrm{~m}$ in core 8510 , however, there are high tritium values, with a maximum of $71 \mathrm{TU}$ at $41.54 \mathrm{~m}$ (Fig. 4). High tritium values have been measured only in the ice at the bottom of core 85-10. Because the other cores were not drilled deep enough, it was not possible to determine whether high tritium values also occurred at the base of the ice at those locations. Nevertheless, the high tritium values in the lowermost $5 \mathrm{~m}$ of core 85-10 set that layer apart from the ice above.

\section{$\delta^{18} \mathrm{O}$ and SEC}

From the surface to the base, the entire thickness of Hobson's Choice Ice Island has very negative $\delta^{18} \mathrm{O}$ values (Fig. 5). The very low SEC values also show that the ice contains few dissolved impurities (Fig. 5). A single high value of $261 \mu \mathrm{S} \mathrm{cm}^{-1}$ is equivalent to a salinity of between only 0.1 and $0.2 \%$, i.e. still a very low level of dissolved impurities. On the basis of the high tritium activity at the base of the ice, two basic layers, stratum A and stratum B, are identified in core 85-10 (Fig. 5). The mean and range of $\delta^{18} \mathrm{O}$ and SEC values in each stratum are presented in Table 1. Since ice cores 86-1, 86-2 and 87-1 did not penetrate stratum $B$, they correspond entirely to stratum A. Their mean $\delta^{18} \mathrm{O}$ and SEC values are also presented in Table 1. The $\delta^{18} \mathrm{O}$ values of stratum $\mathrm{A}$ in each core are very similar. There are a few high SEC values, but as with 
Table 1. Summary of ranges and mean ( \pm 1 standard deviation) for $S E C, \delta^{18} O$ and bulk density data for ice cores 85-10 (strata $A$ and B), 86-1, 86-2 and 87-1, Hobson's Choice Ice Island-East Ward Hunt Ice Shelf. The numbers in parentheses represent the number of samples analysed

\begin{tabular}{llll}
\hline Ice core & \multicolumn{1}{c}{$S E C$} & \multicolumn{1}{c}{$\delta^{18} \mathrm{O}$} & \multicolumn{1}{c}{ Bulk density } \\
& $\mu \mathrm{S} \mathrm{cm}^{-1}$ & & $\mathrm{~kg} \mathrm{~m}^{-3}$ \\
& & & \\
\hline & & & \\
$85-10$ (stratum A) & 2.2 to 32.8 & -34.2 to -25.6 & $\mathrm{~N} / \mathrm{A}$ \\
& $6.9 \pm 3.8(95)$ & $-29.7 \pm 1.7(109)$ & \\
$85-10$ (stratum B) & 3.6 to 262.0 & -32.5 to -28.5 & $\mathrm{~N} / \mathrm{A}$ \\
& $23.6 \pm 61.4(16)$ & $-30.1 \pm 1.6(7)$ & \\
$86-1$ & 1.5 to 252.0 & -33.8 to -24.1 & 665 to 899 \\
& $11.5 \pm 32.7(118)$ & $-29.5 \pm 1.6(64)$ & $870 \pm 21(156)$ \\
$86-2$ & 1.1 to 274.0 & -34.6 to -24.5 & 842 to 906 \\
& $6.3 \pm 25.4(115)$ & $-29.8 \pm 1.9(37)$ & $874 \pm 13(129)$ \\
$87-1$ & 1.1 to 10.1 & -34.3 to -26.1 & 864 to 916 \\
& $3.3 \pm 1.5(206)$ & $-29.7 \pm 1.4(64)$ & $894 \pm 11.7(77)$ \\
\hline
\end{tabular}

that in core $85-10$, they still represent a very low level of dissolved impurities.

\section{Ice-crystal structure and fabric}

The ice crystals in each core are generally equidimensional in individual horizontal sections and,

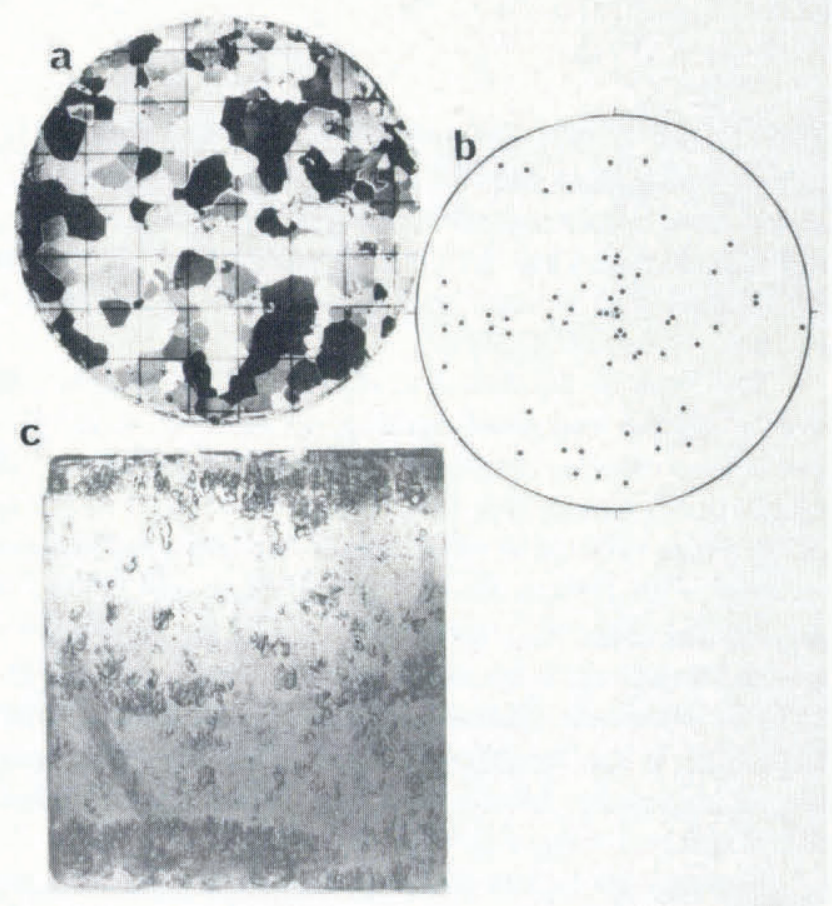

Fig. 6. a. Horizontal thin section of medium texture ice (mean crystal diameter $=6.2 \mathrm{~mm}$ ) from a depth of $7.14 \mathrm{~m}$, ice core $87-1$ (crossed polarizers and $10 \mathrm{~mm}$ grid). b. Fabric diagram for ice in Figure 6a. c. Vertical thick section of ice showing bubbles and evidence of stratification, 7.14-7.23 m, core $87-1$. although there is some size variability, there is no crystal interlocking (Figs 6a, 7a and 8a). Vertically, however, the ice is not homogeneous and on the basis of vertical crystal development, air bubbles and $c$-axis orientations, three basic ice types are identified.

Type 1 ice is invariably granular in texture, of medium grain-size (Fig. 6a) and has random $c$-axis orientations (Fig. 6b). Two types of bubble occur, always together: spherical bubbles typically $0.1-1.0 \mathrm{~mm}$, but occasionally up to $3 \mathrm{~mm}$ diameter; slightly elongate bubbles $2-3 \mathrm{~mm}$ long, with the long axis normal or nearly normal to the ice surface (Fig. 6c). The ice in Figure 6c also shows evidence of stratification, with a $60 \mathrm{~mm}$ thick layer of relatively clear ice sandwiched between thin, bubbly ice layers. Many similar layers are evident throughout the cores, but their number and thickness have not been systematically investigated. Each core also contains a few, thin $(5-30 \mathrm{~mm})$ layers of very bubbly, low-density ice resembling firn.

Type 2 ice is also generally of medium grain-size in cross-section (Fig. 7a), but in vertical sections there are large columnar crystals in addition to a few equant crystals (Fig. 7b). There are spherical bubbles, plus elongate bubbles of $25-30 \mathrm{~mm}$ length oriented normal or nearly normal to the ice surface (Fig. 7b). The tendency for the data to cluster about the centre of the Schmidt net (Fig. 7c) indicates the $c$-axes of the ice crystals are oriented in the near-vertical.

Type 3 ice invariably has a coarse or very coarse texture (Fig. 8a), with large columnar crystals (Fig. 8b) and horizontal $c$-axis orientations. In addition to some spherical and elongate bubbles, this ice often contains tubular bubbles $1-2 \mathrm{~mm}$ in diameter, as much as $300 \mathrm{~mm}$ long and oriented normal to the ice surface (Fig. 8b).

\section{Bulk density}

The bulk-density data for cores $86-1,86-2$ and $87-1$ are summarized in Table 1. Although core $87-1$ is slightly 


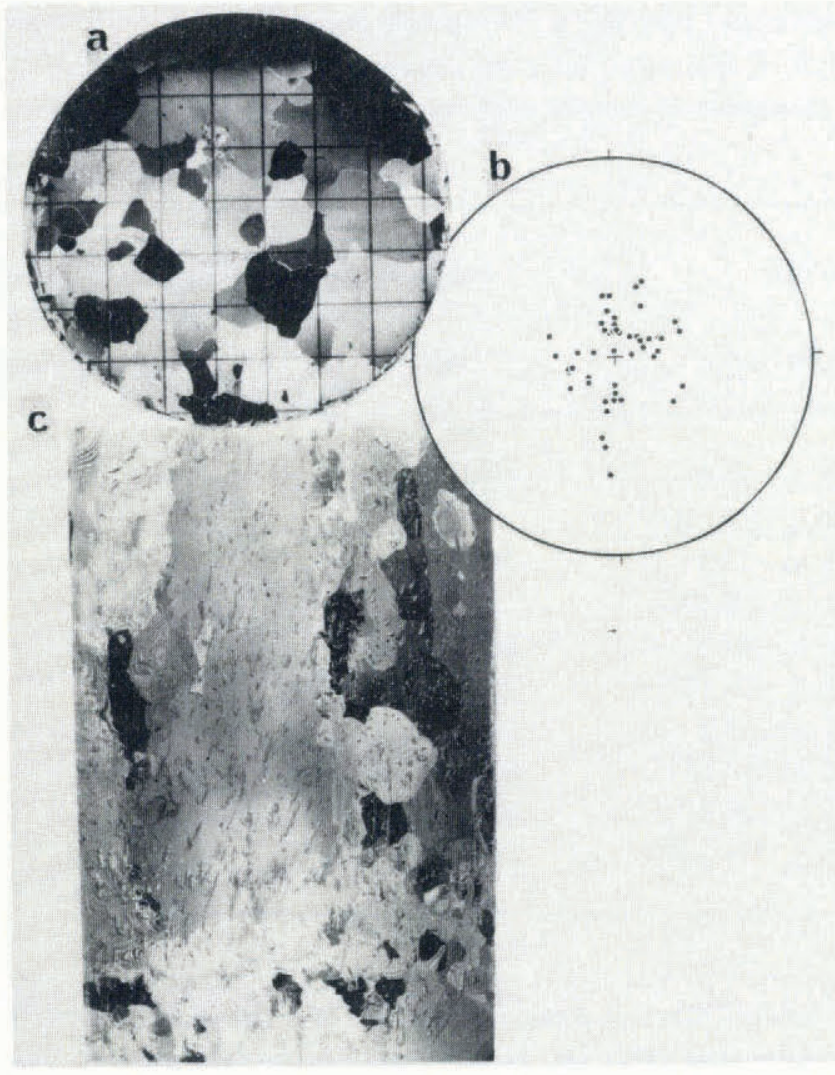

Fig. 7. a. Horizontal thin section of medium texture ice (mean crystal diameter $=9.8 \mathrm{~mm}$ ) from a depth of $28.90 \mathrm{~m}$, core $87-1$ (crossed polarizers and $10 \mathrm{~mm}$ grid). b. Fabric diagram for ice in Figure 7a. c. Vertical thick section $(63 \mathrm{~mm}$ wide, $100 \mathrm{~mm}$ long in crossed polarizers) of columnar ice with highly elongate bubbles (arrows), 28.90-29.00 m, core 87-1.

more dense than cores $86-1$ and $86-2$, they essentially have very similar density ranges and mean values. The mean and range of density values for cores $86-1$ and $86-2$ are particularly alike, and each density profile shows density increasing towards the bottom of each core (Fig. 9). The low value of $665 \mathrm{~kg} \mathrm{~m}^{-3}$ in core $86-1$ occurred at the ice surface where melting along grain boundaries the previous summer had created a loose agglomeration of crystals similar to candled ice.

\section{Ice types and their origin}

\section{Surface accumulation}

Ragle and others (1964) referred to the ice that had accumulated at the surface of Ward Hunt Ice Shelf during periods of positive mass balance as "glacier ice". However, as noted in section II, there is no evidence that any part of Ward Hunt Ice Shelf originated from glaciers. Marshall $(1955,1960)$ used the term "iced-firn" to describe ice that had accumulated by the thawing and refreezing of snowpack on the ice shelves. Koerner (1968) used the term "depositional ice", which includes firn ice and superimposed ice, some of which has random $c$-axis orientations and no bubble stretching. Superimposed ice accumulates as water percolating through the snow or firn directly in contact with the ice refreezes, or as water

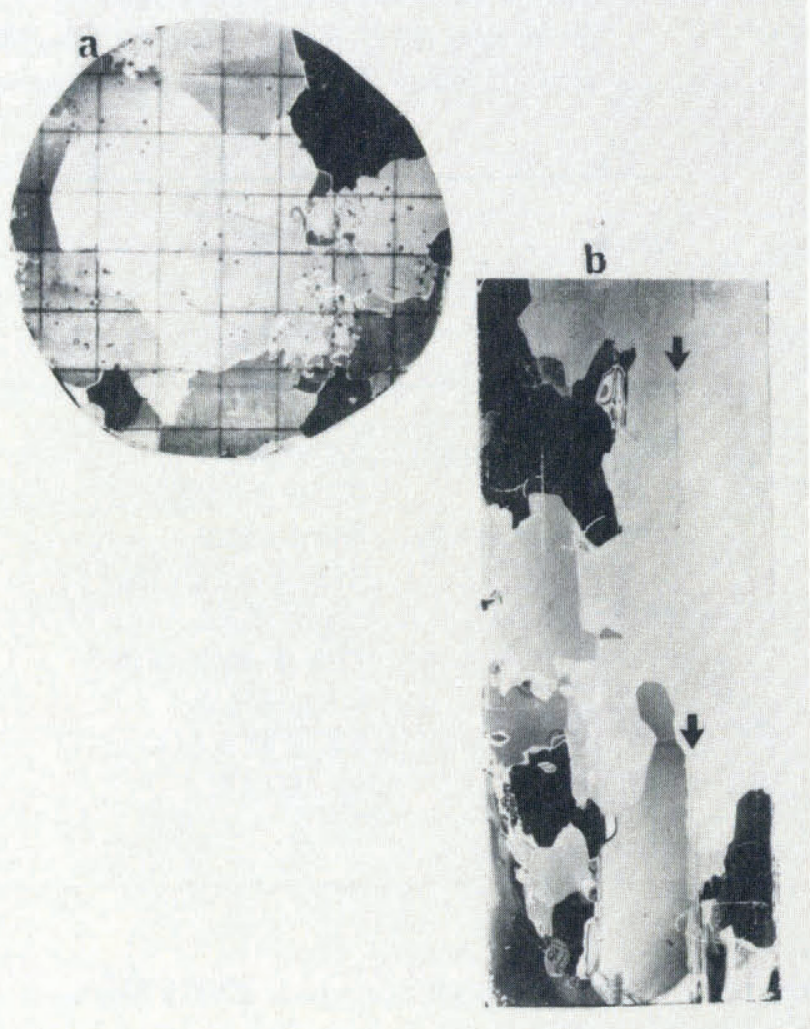

Fig. 8. a. Horizontal thin section of coarse texture ice (mean crystal diameter $=19.8 \mathrm{~mm}$ ) from a depth of $19.78 \mathrm{~m}$, core $86-2$ (cross polarizers with a $10 \mathrm{~mm}$ grid). $b$. Vertical thick section (60 $\mathrm{mm}$ wide, $200 \mathrm{~mm}$ long in crossed polarizers) of columnar ice with tubular bubbles (arrows), 19.78-19.98 m, core 86-2.

flowing over a bare ice surface freezes (Koerner, 1970). The three ice types identified in the Hobson's Choice Ice Island cores closely resemble different types of depositional and superimposed ice. The combination of low $\delta^{18} \mathrm{O}$ and SEC values (Fig. 4 and Table 1 ) is additional evidence of ice that originated as snow.

The type 3 ice has the characteristics of lake ice formed by the sustained freezing of standing water, i.e. coarse/very coarse columnar ice with horizontal $c$-axis orientations and tubular bubbles (e.g. Gow and Langston, 1977). Huge lakes have been observed in the superimposed ice zone of the Devon Island Ice Cap (Koerner, 1970). In view of the lakes that presently form in the ice shelf-ice island depressions, it is not considered unusual to find lake ice in the Hobson's Choice Ice Island cores. Lake-ice lenses embedded in the iced-firn at Ward Hunt Ice Shelf were also identified by Marshall (1955, 1960), Crary (1958) and Ragle and others (1964).

The lake ice in the Hobson's Choice Ice Island cores indicates complete saturation of the snow cover followed by melting and run-off into pools and lakes. Koerner (1970) reported that in cases where the snow cover becomes completely saturated, but little or no run-off occurs, slush ice with vertical c-axes forms. The type 2 in Hobson's Choice Ice Island is considered to be slush ice. Type 1 ice represents the least saturation of the snow cover and, for it, the old term "iced-firn" is retained. 


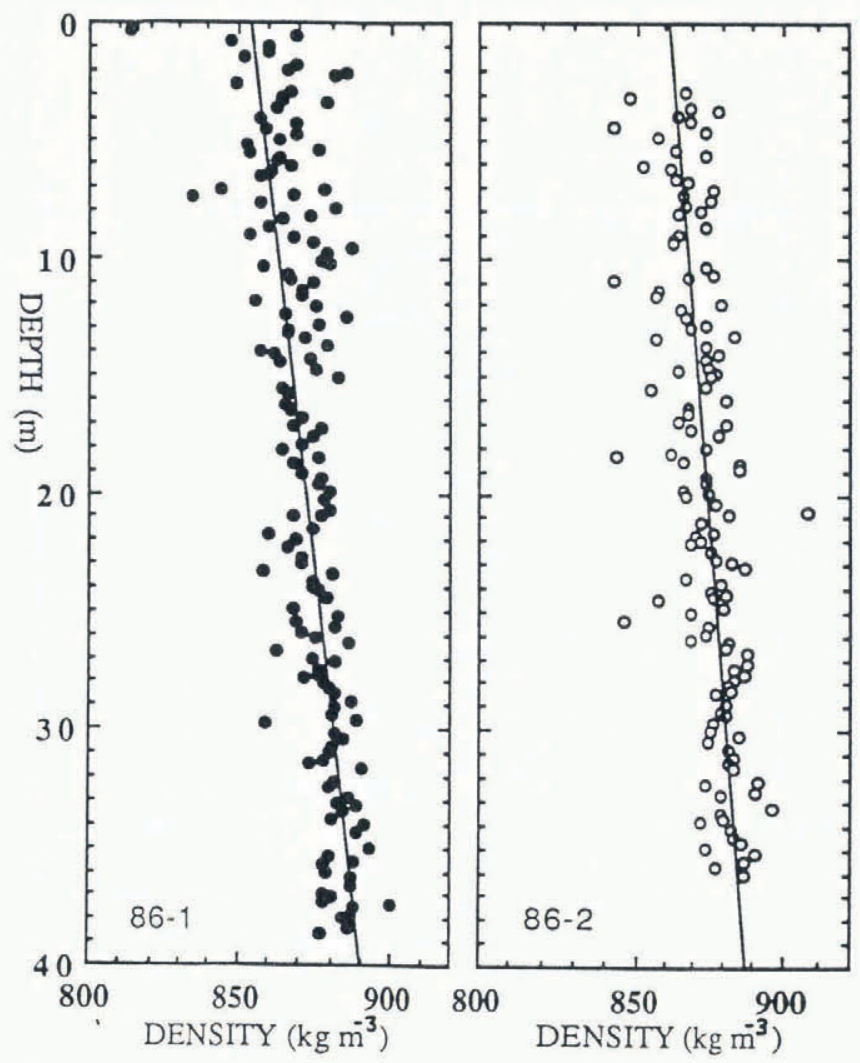

Fig. 9. Bulk density variations as a function of depth in cores 86-1 (left) and 86-2 (right). The straight lines are represented by the following regression equations, each with a correlation coefficient of 0.6 significant at the $95 \%$ confidence level: core $86-1$, density $=0.88$, depth $+858 \mathrm{~kg} \mathrm{~m}^{-3}$; core $86-2$, density $=0.88$, depth $+862 \mathrm{~kg} \mathrm{~m}^{-3}$. The minimum value of $665 \mathrm{~kg} \mathrm{~m}^{-3}$ at the top of core 86-1 has not been plotted.

No matter what the condition of the snow cover and whether run-off occurred, each of the three ice types represents accumulation due to the rapid transformation of snow to ice in the duration of one summer, and probably in the upper surface metre or less of the ice shelf. The progressive accumulation of ice at the surface of the ice shelf would increase the overburden pressure, which might account for the observed increase in density towards the base of stratum A (Fig. 9).

\section{Basal processes}

It is generally accepted that the entire Ward Hunt Ice Shelf originated as thick, landfast sea ice and that sea-ice basement or proto-ice-shelf thickened further by surface accumulation and/or bottom accretion. It was noted in section II that thick layers of sea ice and brackish ice, some perhaps the original basement ice, and still overlain by superimposed ice, remain in the western and southern parts of Ward Hunt Ice Shelf. In contrast, although the cores from Hobson's Choice Ice Island contain a record of surface accumulation and bottom accretion, it is apparent that there is no longer any sea ice contained in a large part of East Ward Hunt Ice Shelf.

Initially, it was believed that any former sea ice had been lost by surface ablation when bottom accretion accompanied surface lowering (Jeffries and others, 1988).
Now, with the evidence of the surface accumulation of almost $40 \mathrm{~m}$ of depositional-superimposed ice, sea-ice loss at the surface cannot have occurred and it must be concluded that the original sea ice was removed by bottom melting. It is also quite possible that bottom melting removed ice from the base of stratum $A$ prior to the accretion of stratum B, including some or all of the first ice to accumulate on the original sea-ice platform c. $3000 \mathrm{BP}$.

Since 1952, atmospheric tritium levels have exceeded natural background levels due to the injection of tritium resulting from above-ground thermonuclear bomb tests (Gat, 1980). The absence of high anthropogenic values at any depth in the ice above $38.70 \mathrm{~m}$ (Fig. 4) is consistent with a negative ice-shelf-surface mass balance this century (see section II) and the measured natural background levels of tritium are to be expected. Only in the thin annual lake-ice layers at the surface of the depression lakes are anthropogenic tritium levels as high as $125 \mathrm{TU}$ found, indicating recent accumulation from snow-meltwater, the main component of the lakes (Jeffries, 1985). Since the elevated tritium levels at the base of the ice island are of the same order of magnitude as those in the surface lakes, it suggests that both are contemporaneous and snow meltwater also may be the source of the lowermost iceisland-ice-shelf layer.

The highly negative $\delta^{18} \mathrm{O}$ values associated with the high tritium values in stratum B (Fig. 4 and Table 1) are additional evidence of a precipitation source, since they are similar to recent snowfall $\delta^{18} \mathrm{O}$ values in this region (Jeffries and Krouse, 1987). They also discount the possibility that the ice accumulated by accretion of sea ice after the calving in 1982-83 when the ice island began to drift in sea water; the $\delta^{18} \mathrm{O}$ values of sea water are typically close to zero per mil $(0 \%$ ), considerably more positive than those in stratum B (Table 1). The most plausible origin of ice with high tritium values at the base of the ice island is ice accretion at the base of East Ward Hunt Ice Shelf prior to the calving, from a fresh-water layer of precipitation origin.

The most likely source of fresh water is Disraeli Fiord, south of the ice shelf (Fig. 1). There, the $44 \mathrm{~m}$ deep freshwater layer of snow-meltwater origin at the fiord surface also has negative $\delta^{18} \mathrm{O}$ values, and tritium levels of the same order of magnitude as those at the base of the ice island (Jeffries, 1985). It has been believed for some time that water from the surface of Disraeli Fiord flows north below Ward Hunt Ice Shelf and that ice accretes to the base of the ice shelf from this low-salinity water (Lyons and others, 1971; Keys, 1978). Frazil and platelet ice is known to grow due to supercooling at the halocline in the fiord (Keys, 1978) and it is quite possible that this process also occurs at the base of the eastern ice shelf. In the absence of ice-texture and fabric data, though, the growth processes cannot be identified with certainty at this time. Nevertheless, a fresh-water outflow from Disraeli Fiord remains the most probable source of water for ice accretion at the base of Ward Hunt Ice Shelf and thus the source of the lowermost $5 \mathrm{~m}$ layer of Hobson's Choice Ice Island.

Jeffries (in press) calculated a mean basal accretion rate of $96 \mathrm{~mm} \mathrm{a}^{-1}$ (water equivalent) for the interval 195282 and a rate of $141 \mathrm{~mm} \mathrm{a}^{-1}$ for the interval 1963-82. Both rates exceed the mean annual surface losses of $74 \mathrm{~mm} \mathrm{a}^{-1}$ since the mid-1960s and it has been concluded that the 
outflow of fresh water from the fiord presently plays a significant role in the overall mass balance of the eastern ice shelf, where the thickness is at least being maintained and perhaps even increased slightly (Jeffries, in press).

The accretion of stratum B post-dates the certain loss of the original sea-ice platform. Basal melting is implicated in the loss of sea ice, and perhaps some ablation losses of the oldest superimposed ice. Thus, stratum A now rests unconformably on stratum B.

\section{STRUGTURAL-STRATIGRAPHIC VARIABIL- ITY IN STRATUM A}

On the basis of $\delta^{18} \mathrm{O}$ and tritium values, and ice-crystal structure and fabric variations, a basic two-layer stratigraphy has been identified in Hobson's Choice Ice IslandEast Ward Hunt Ice Shelf. Most of the ice (stratum A) has accumulated from snowpack at the surface of the ice shelf and raises the question of whether the ice contains any kind of record of past variations in the surface regime. In this section, $\delta^{18} \mathrm{O}$ and ice-crystal structure and size variations in cores $86-1,86-2$ and $87-1$ are described and possible causes and consequences of the stratigraphic variability related to surface processes and conditions are discussed.

\section{$\delta^{18} \mathbf{O}$}

The $\delta^{18} \mathrm{O}$ profile for core $87-1$ has been divided into three layers: A-I, A-II and A-III (Fig. 10). The grounds for this division are discontinuities in the isotopic profile and variations in $\delta^{18} \mathrm{O}$ values that give rise to a middle layer (A-II) with somewhat more negative $\delta^{18} \mathrm{O}$ values than the top (A-III) or bottom (A-I) layers. A similar three-layer stratigraphy has been identified in cores $85-10,86-1$ and $86-2$ according to the clustering of $\delta^{18} \mathrm{O}$ values and

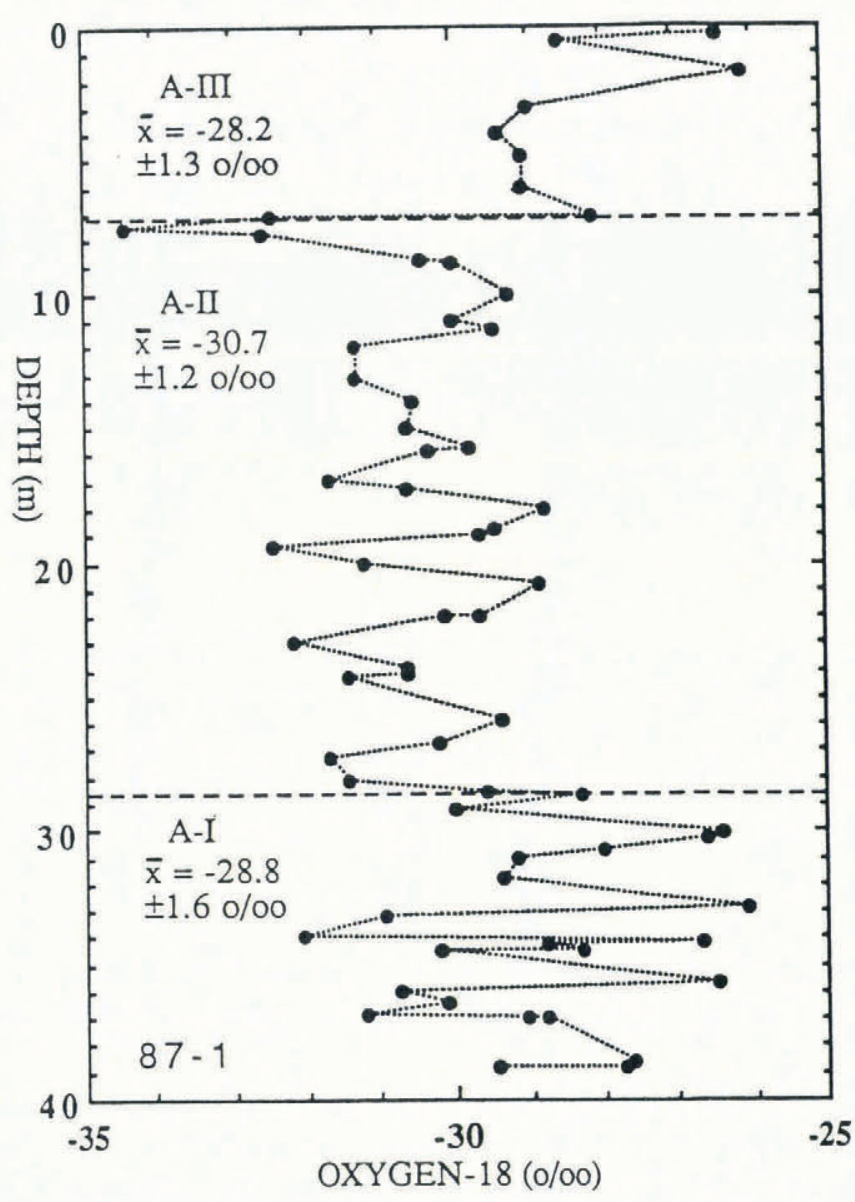

Fig. 10. $\delta^{18} O$ profile in core $87-1$. The three sub-strata, $A-I$, $A-I I$ and $A-I I I$, are denoted by the horizontal dashed lines. The mean $\delta^{18} \mathrm{O}$ values for each sub-stratum are also shown.

discontinuities in the isotopic profiles. The mean and range of $\delta^{18} \mathrm{O}$ values in each of the three sub-strata in cores $85-10,86-1,86-2$ and $87-1$ are summarized in Table 2 .

Table 2. Depth intervals, and $\delta^{18} \mathrm{O}$ ranges and means ( \pm 1 standard deviation) for the three sub-strata of stratum A in Hobson's Choice Ice Island-East Ward Hunt Ice Shelf. The numbers in parentheses represent the number of samples analysed

Ice core Stratum A-III Stratum A-II Stratum A-I

\begin{tabular}{|c|c|c|c|}
\hline $85-10$ & $\begin{array}{l}0.0 \text { to } 7.7 \mathrm{~m} \\
-32.6 \text { to }-25.6 \% \\
-28.5 \pm 1.8 \% \text { o }\end{array}$ & $\begin{array}{l}7.7 \text { to } 28.55 \mathrm{~m} \\
-34.2 \text { to }-27.1 \% \\
-30.2 \pm 1.8 \%\end{array}$ & $\begin{array}{l}28.55 \text { to } 38.7 \mathrm{~m} \\
-31.7 \text { to }-25.8 \% \\
-29.0+1.5 \%\end{array}$ \\
\hline $6-1$ & $\begin{array}{l}0.0 \text { to } 9.0 \mathrm{~m} \\
-31.4 \text { to }-24.7 \% \text { o } \\
-28.2 \pm 2.1 \% \text { (12) }\end{array}$ & $\begin{array}{l}9.0 \text { to } 28.13 \mathrm{~m} \\
-33.8 \text { to }-28.1 \% \text { o } \\
-30.5 \pm 1.4 \% \text { (22) }\end{array}$ & $\begin{array}{l}28.13 \mathrm{~m}+ \\
-31.6 \text { to }-24.1 \% 0 \\
-29.2 \pm 1.6 \% \text { (30) }\end{array}$ \\
\hline $86-2$ & $\begin{array}{l}0.0 \text { to } 4.11 \mathrm{~m} \\
-29.6 \text { to }-26.4 \% \text { o } \\
-28.3 \pm 1.4 \% \text { (4) }\end{array}$ & $\begin{array}{l}4.11 \text { to } 30.85 \mathrm{~m} \\
-34.6 \text { to }-27.5 \% \\
-30.2 \pm 1.7 \% \text { ( } 24)\end{array}$ & $\begin{array}{l}30.85 \mathrm{~m}+ \\
-32.5 \text { to }-24.5 \% \\
-29.5 \pm 2.7 \%(9)\end{array}$ \\
\hline $87-1$ & $\begin{array}{l}0.0 \text { to } 7.38 \mathrm{~m} \\
-29.4 \text { to }-26.1 \% \text { o } \\
-28.2 \pm 1.3 \% \text { ( } 8)\end{array}$ & $\begin{array}{l}7.38 \text { to } 28.65 \mathrm{~m} \\
-34.3 \text { to }-28.8 \% \text { o } \\
-30.7 \pm 1.2 \% \text { o }(32)\end{array}$ & $\begin{array}{l}28.65 \mathrm{~m}+ \\
-32.1 \text { to }-26.1 \% 0 \\
-28.8 \pm 1.6 \% \text { (24) }\end{array}$ \\
\hline
\end{tabular}


A one-way analysis of variance (ANOVA) shows there are (1) statistically significant differences in the mean $\delta^{18} \mathrm{O}$ values of the three sub-strata within individual cores, with the possible exception of core 86-2 (Appendix A), but (2) no statistically significant between-core differences in the mean $\delta^{18} \mathrm{O}$ values of a given sub-stratum, e.g. there is no statistically significant difference between the mean $\delta^{18} \mathrm{O}$ values of stratum A-I in each of the four cores (Appendix B). Although the ANOVA of core 86-2 suggests it is more homogeneous than the other cores, there is still a better than $82 \%$ probability (Table A-III in Appendix A) of being correct in assuming there are statistically significant differences between the sub-strata.

The results of the one-way ANOVA are sufficiently encouraging to proceed to a more robust two-way ANOVA. The ANOVA table shows there is an almost $80 \%$ probability that the two factors, the sub-strata and the cores, were not interacting. This adds to the power of the ANOVA and favours the conclusion that there are statistically significant within-core differences in the $\delta^{18} \mathrm{O}$ values of the three sub-strata, but no significant betweencore differences (Appendix C).

\section{Ice-crystal structure and size}

Ice-crystal size profiles identifying the occurrence of icedfirn, slush ice and lake ice in cores 86-1 and 86-2 are presented in Figure 11. The sub-strata A-I, A-II and AIII previously identified according to $\delta^{18} \mathrm{O}$ variations are marked and it can be seen that they also coincide with icecrystal size and structural variations. Note that the crystaldiameter scale for core $86-2$ is compressed by a factor of two compared to that of core 86-1; hence, the variations in ice-crystal diameters are somewhat larger than are immediately apparent.

The middle layer of core $86-1$ is entirely iced-firn with mean crystal diameters all $<10 \mathrm{~mm}$. This contrasts sharply with the middle layer of core 86-2, which comprises icedfirn, slush ice and lake ice with ice-crystal diameters of as much as $46.6 \mathrm{~mm}$. In both cores the bottom layer comprises iced-firn and slush ice, but the crystal diameters are a little larger in core 86-2. Substratum AIII in core $86-2$ is very thin and thus difficult to compare

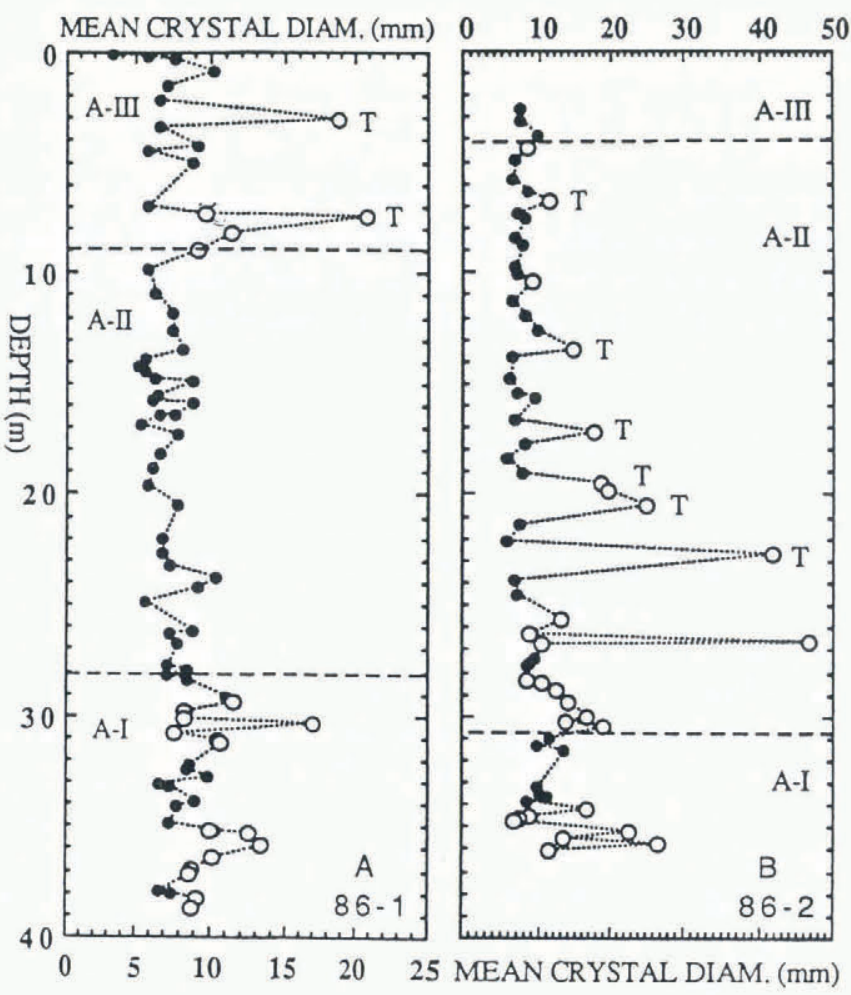

Fig. 11. Ice-crystal size variations in cores 86-1 (a: left) and 86-2 (b: right). Solid circles represent granular iced-firn, unaccompanied open circles denote columnar slush ice, and open circles accompanied by a $T$ represent lake ice with tubular bubbles. Also illustrated as horizontal dashed lines are the boundaries between the three sub-strata, A-I, A-II and A-III.

objectively with the top layer of core 86-1. However, it is worth noting that the larger crystal sizes of the slush and lake ice in the top layer of core 86-1 contrast with the uniform iced-firn layer below. Although the ANOVA of the core $86-2 \delta^{18} \mathrm{O}$ data suggest it is more homogeneous than the other cores, the qualitative within-core ice-crystal size and structure differences in core $86-2$ and the differences between cores $86-1$ and $86-2$ indicate that core $86-2$ is far from homogeneous and favours the division into three sub-strata.

Table 3. Ranges and means ( \pm 1 standard deviation) of ice-crystal diameter values ( $\mathrm{mm})$ for three substrata identified in stratum $A$, ice cores 86-1, 86-2 and 87-1, Hobson's Choice Ice Island-East Ward Hunt Ice Shelf. Numbers in parentheses represent the number of horizontal thin sections for which a mean crystal diameter value was determined

Ice core Stratum A-III Stratum A-II Stratum A-I

$86-1$

$86-2$

$87-1$
3.3 to 20.8

$9.2 \pm 4.5(16)$

7.3 to 9.8

$8.2 \pm 1.1$

N/A
5.2 to 10.4

$7.2 \pm 1.2(33)$

6.6 to 17.0

$9.4 \pm 2.2(27)$

5.7 to 46.5

6.8 to 26.8

$11.3 \pm 9.1(47)$

$12.2 \pm 4.7$

6.3 to 20.8

4.8 to 10.3

$10.4 \pm 3.6(30)$ 
Similar occurrences of each ice type and patterns of ice-crystal diameter variability were found in core 87-1. The mean and range of ice-crystal diameter values in each of the three sub-strata in cores 86-1, 86-2 and 87-1 are summarized in Table 3. Analysis of variance of those data has not been done, as the differences between the substrata are considered to be sufficiently evident and in accord with those identified by analysis of variance of the conservative tracer, $\delta^{18} \mathrm{O}$.

\section{Thickness of sub-strata A-I, A-II and A-III}

In addition to the within-core and between-core differences in $\delta^{18} \mathrm{O}$ and ice-crystal size-ice-type variations in the three sub-strata of stratum $\mathrm{A}$, there are also within-core and between-core differences in the thickness of the individual strata (Table 2). Strata A-I, A-II and A-III in cores $86-1$ and $87-1$ are each of similar thickness. On the other hand, stratum A-II in core 86-2 is the thickest of all the strata, its top being at a shallower depth and the base being deeper than the inter-layer boundaries in the other cores (e.g. Fig. 11b). For example, the top of stratum A-II in core $86-2$ is $4.89 \mathrm{~m}$ higher than in core $86-1$, while the base of stratum A-II in core $86-2$ is $2.72 \mathrm{~m}$ lower than in core 86-1 (Fig. 11). The variations in the thickness of the sub-strata are illustrated in Figure 12 and the implications of the inferred stratigraphic variations are discussed below.

\section{Discontinuous surface accumulation}

It has already been noted that bottom melting could have removed some of the ice that initially began to accumulate on the original sea-ice platform of the eastern ice shelf. Ice losses by surface ablation might also have occurred, since, as the ice-crystal structures indicate, meltwater has been a major factor in the build-up of ice at the surface.

As a consequence of the negative mass-balance regime during the greater part of this century, there has been considerable ice loss from the surface and many years of previous ice accumulation have been removed (Hatters-

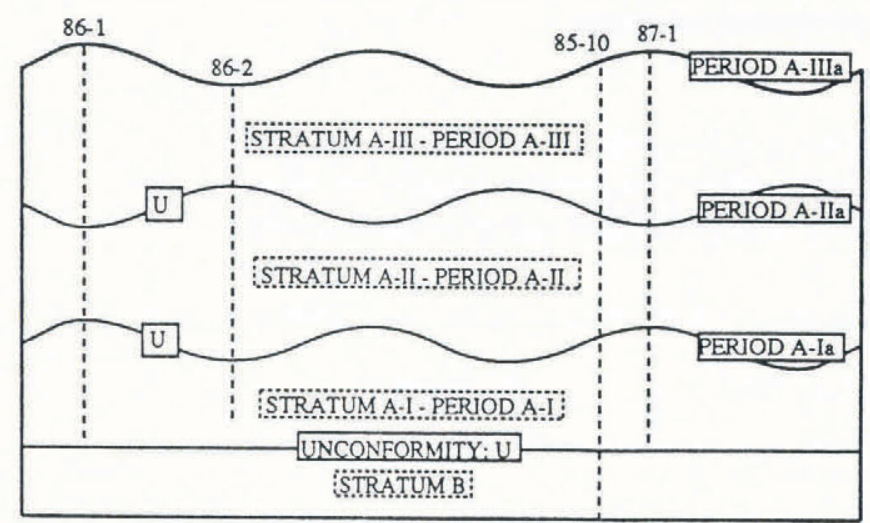

Fig. 12. Diagrammatic representation of the present surface of Hobson's Choice Ice Island and ice-core locations, the iceisland-ice-shelf stratigraphy of the two primary strata $(A$ and $B)$ and three secondary strata (A-I, A-II and A-III) representing major accumulation periods, unconformities representing major ablation periods ( $A$-Ia, A-IIa and $A$ IIIa), and inferred topographic changes at past ice-shelf surfaces. Not to scale.
ley-Smith and Serson, 1970; Serson, 1979). If positive mass-balance conditions were to resume, the new ice would rest unconformably upon the old and a relict ablation surface would mark the boundary. In ice cores from elsewhere in the Canadian High Arctic, e.g. Meighen Ice Cap (525 km southwest of Ward Hunt Ice Shelf), relict ablation surfaces have been identified by $\delta^{18} \mathrm{O}$ and icecrystal-size discontinuities separating unconformable ice layers with contrasting properties (Koerner, 1968; Koerner and others, 1973; Koerner and Paterson, 1974).

Similar phenomena have been identified in the Hobson's Choice Ice Island cores and it is believed that the boundaries between the sub-strata in stratum A also are relict ablation surfaces, representing previous episodes when many years of accumulated ice were lost. Long-term accumulation on the ice-shelf surface evidently has been discontinuous and the three sub-strata of stratum $\mathrm{A}$, which represent three major accumulation periods (periods A-I, A-II and A-III; Fig. 12), are unconformable (denoted U in Figure 12). In addition to the present period of negative surface mass balance (period A-IIIa, Fig. 12), the ice-core records indicate there have been two previous major periods of surface lowering (periods A-Ia and A-IIa; Fig. 12). Consequently, the ice cores contain an incomplete record of accumulation at the surface of East Ward Hunt Ice Shelf.

On the basis of early ice-core studies of ice island T-3 and Ward Hunt Ice Shelf west and southwest of Ward Hunt Island, only one major ablation period was identified and it was marked by a visible concentration of dust (Marshall, 1955, 1960; Crary, 1958, 1960). No visible dust horizons were found in the Hobson's Choice Ice Island cores and their absence may be a consequence of distance from local dust sources. The discovery of an additional ablation period may be due to the greater depth from which we obtained cores, or perhaps because previous investigators had measured too few ice-core parameters to enable recognition of an additional warm interval in their cores.

Marshall $(1955,1960)$ estimated a water-equivalent accumulation varying between 76 and $133 \mathrm{~mm} \mathrm{a}^{-1}$. The stratified ice illustrated in Figure $3 \mathrm{c}$ suggests $52 \mathrm{~mm} \mathrm{a}^{-1}$ of water-equivalent accumulation, but other stratified ice layers are thicker, indicating greater annual accumulation. Because of the incomplete accumulation record, detailed determinations of past surface-accumulation rates at East Ward Hunt Ice Shelf have not been attempted. The discontinuous accumulation record also precludes accurate dating of the ice and thus identification of the timing of the warm intervals. The one warm interval identified in earlier ice cores may have ended c. $1600 \mathrm{BP}$ (Crary, 1960), which coincides with a warm interval postulated c. 2400-1400 BP (Lyons and Mielke, 1973). However, those estimates were based on somewhat unreliable data and inappropriate comparisons with other palaeo-environmental records; hence, no attempt has been made here to postulate dates for the timing of the ablation periods identified in the Hobson's Choice Ice Island cores.

\section{Surface topographic changes}

According to Figure 12 the period A-Ia unconformity in 
each core, i.e. the top of stratum A-I, has the same configuration as the present surface. On the other hand, the period A-IIa unconformity in each core apparently is $180^{\circ}$ out of phase with the present surface and the unconformity below. This suggests that the accumulation of stratum A-II occurred on a relict ablation surface with a topography similar to the present topography, i.e. hummocks at the sites of cores $86-1$ and $87-1$, whereas the accumulation of stratum A-III occurred when there was a hummock at the present site of core 86-2 and depressions at the present sites of the other cores.

The changing configuration of the unconformities implies an inversion of relief. Further, since the unconformities represent ablation periods, the topographic changes must have occurred during the prolonged ablation periods. It is generally accepted that the undulations are primarily ablation features and their persistence is related to the combined influence of prevailing winds and relatively warm lake water, which cause melt-pool elongation and coalescence (HattersleySmith, 1957; Crary, 1960). The inversion of relief inferred from the Hobson's Choice Ice Island ice-core records is consistent with previous observations of ablation-related topographic changes on ice island T-3 (Crary, 1958; Smith, 1961) and on Ward Hunt Ice Shelf where the phenomenon was described as a long-term migration of the rolls (Lister, 1962).

The differences in the thickness of the individual strata from core to core, and the depth differentials between their tops and bottoms, are a measure of the relative relief of the former undulations. Thus, for example, the depth differentials between the unconformities at the top and base of stratum A-II in cores $86-1$ and $86-2$ (Fig. 11) represent the depth of the depressions from hummock crest to depression bottom. Lister (1962) summarized the measured depression-depth data, which varied spatially from 0.4 to $3.5 \mathrm{~m}$, with an overall mean value of $2.05 \mathrm{~m}$ on Ward Hunt Ice Shelf. The relative relief variations of the former undulations (4.89 and $2.72 \mathrm{~m}$ ) are consistent with the present relief and indicate that, although the siting of hummocks and depressions may have changed considerably, no unusual changes occurred in their dimensions.

The inferred changes in the spatial arrangement of the hummocks and depressions would have caused considerable temporal variations in the drainage conditions at the surface of the ice shelf. This would account for much of the variation of ice-crystal structure and size in the ice cores. The depressions would have tended to be wetter than the adjacent hummocks and consequently, as observed in cores 86-1 and 86-2, a greater amount of slush and lake ice would occur there (Fig. 12). The contrast between relatively dry, well-drained hummocks and wetter, less well-drained depressions is less evident in stratum A-I (e.g. Fig. 12) where slush ice is a significant component in each of the three cores. This might be evidence of a generally less well-developed surface-drainage system during period A-I than during the two later accumulation periods.

\section{DISCUSSION AND SUMMARY}

Primarily on the basis of $\delta^{18} \mathrm{O}$ and tritium data for core $85-10$, it was previously concluded that East Ward Hunt
Ice Shelf is a homogeneous slab of fresh-water ice, as a result of a 400-500 year period of surface ablation accompanied by bottom accretion of ice from fresh water flowing below the ice shelf (Jeffries and others, 1988). The results of further ice-core analysis now show that East Ward Hunt Ice Shelf is far from homogeneous. Two primary ice layers of different origin have now been identified: stratum A represents surface accumulation of ice from snowpacks; stratum B represents recent bottom accretion from fresh water.

\section{Stratum A}

Stratum A includes the uppermost $35-38 \mathrm{~m}$ of the ice island and is all depositional-superimposed ice comprising three ice types: iced-firn, slush ice and lake ice. Within stratum A, three secondary layers or sub-strata, A-I, A-II and A-III, have been identified according to stratigraphic discontinuities in the $\delta^{18} \mathrm{O}$ profiles and ice-crystal structure and size variations. The three sub-strata represent three major periods of accumulation interrupted by three major ablation periods during which previous accumulations of ice must have been lost. Consequently, the accumulation record in stratum $\mathrm{A}$ is incomplete and it is difficult to estimate accumulation rates or to assign absolute dates to any part of it.

In addition to the identification of the accumulation periods and ablation periods, the down-core variations in $\delta^{18} \mathrm{O}$ and ice-crystal structure and size variations have enabled other palaeo-environmental changes to be identified. First, even during the cooler periods of surface accumulation, the regime was dominated by meltwater, which played a key role in the transformation of snow to the three categories of ice. Secondly, significant topographic changes, amounting to an inversion of the relief, occurred during the warmer ablation periods as the surface was lowered.

The pervasive effects of meltwater and the topographic changes make it difficult to advance beyond these general palaeo-environmental interpretations of the Hobson's Choice Ice Island cores. The topographic influences on the ice physical properties, structural characteristics and stratigraphy probably exceed climatological influences and mask palaeoclimatic signals in the cores. For a complete discussion of the specific problems associated with the palaeoclimatic interpretation of icecore records, particularly of $\delta^{18} \mathrm{O}$ data, from locations where meltwater influences and topographic changes have been significant, the reader is referred to Koerner (1968), Koerner and others (1973) and Koerner and Paterson (1974).

\section{Stratum B}

Stratum B at the base of the ice shelf is a little over $5 \mathrm{~m}$ thick and its high tritium values indicate that it has accreted only since 1952 at the earliest. Consequently, other than the contemporary lake ice at the surface, stratum B is the youngest ice in the eastern ice shelf. The most plausible source of the ice and the tritium is accretion from fresh water flowing out of Disraeli Fiord beneath East Ward Hunt Ice Shelf. The accretion of stratum B supports the original conclusion of a sea-water inflow below the 
western ice shelf into Disraeli Fiord, and an outflow, including fresh-water-sea-water stratification, below the eastern ice shelf (Jeffries and others, 1988; fig. 6).

In view of the age of stratum $B$, it is certain that stratum A did not accumulate on it. Instead, since the entire Ward Hunt Ice Shelf in all probability originated as a thick sea-ice sheet across the mouth of Disraeli Fiord c. $3000 \mathrm{BP}$, it is reasonable to assume that stratum A began to accumulate on that sea ice and thus contains no ice older than 3000 years. The sea ice no longer exists and strata $\mathrm{A}$ and $\mathrm{B}$ are unconformable.

The present perennial availability of a large volume of fresh water in Disraeli Fiord and its outflow below the ice shelf must be related, at least in part, to the warm summers that have prevailed in this region for the greater part of this century. For the same reason, it may be assumed that large volumes of fresh water were available in Disraeli Fiord during the previous two warm climatic intervals. The outflow of that water below the ice shelf was probably responsible for the melting and eventual removal of the original sea ice on which stratum A began to accumulate. But why there should have been bottom accretion during just the last 35-40 years rather than further bottom melting, as has happened apparently during the previous warm episodes, is unclear. In addition to climatic influences, variability in the sub-iceshelf water circulation and thermal regime probably also play an inportant role in basal processes.

\section{CONCLUSION}

The growth history of East Ward Hunt Ice Shelf has been more complex than was originally concluded by Jeffries and others (1988). The previous, simple model of a 400500 year surface-ablation period balanced by bottom accretion to produce a homogeneous fresh-water ice sheet was formulated in the absence of crystallographic data. The addition of crystallographic data and a re-examination of the original $\delta^{18} \mathrm{O}$ and tritium data has provided compelling evidence of previous periods of substantial accumulation and ablation at the surface, considerable bottom melting in the past, as well as modern basal accretion at East Ward Hunt Ice Shelf. The analysis of multiple cores from Hobson's Choice Ice Island also has revealed evidence of past topographic changes at the surface of the ice shelf. Thus, in addition to documenting ice physical-structural property variations, identifying different ice types, and delineating the stratigraphy of the ice island, plus elucidation of some aspects of ice-shelf surface and bottom processes, this study has illustrated the value of multi-parameter analysis of multiple ice cores from a given locality, where possible.

\section{ACKNOWLEDGEMENTS}

This work has been supported by the U.S. Department of Energy, Morgantown Energy Technology Centre (Arctic/ Offshore Program) and the Geophysical Institute, University of Alaska Fairbanks. Logistical support for work on Hobson's Choice Ice Island and Ward Hunt Ice Shelf has been provided by the Polar Continental Shelf Project. The
Stable Isotope Laboratory, University of Calgary, is supported by the Natural Sciences and Engineering Research Council of Canada. O.-P. Nordlund, J. Poplin and D. Smith assisted with the ice-core drilling, L. Loadman surveyed the ice-core positions and M. Schmidt provided support and encouragement on Hobson's Choice Ice Island. K. Morris and J. Groves helped with ice-core transportation from Whitehorse to Fairbanks. Dr P.X. Quang gave advice on the analysis of variance. One of us (M.O.J.) is particularly grateful for Dr R. M. Koerner's continued interest in the ice-shelf research over the years and for his review of this particular paper.

\section{REFERENCES}

Crary, A. P. 1958. Arctic ice island and ice shelf studies. Part I. Arctic, 11(1), 3-42.

Crary, A. P. 1960. Arctic ice island and ice shelf studies. Part II. Arctic, 13(1), 32-50.

Gat, J.R. 1980. The isotopes of hydrogen and oxygen in precipitation. In Fritz, P. and J. C. Fontes, eds. Handbook of environmental isotope geochemistry. Vol. I. The terrestrial environment. Amsterdam, Elsevier, 21-47.

Gow, A.J. and D. Langston. 1977. Growth history of lake ice in relation to its stratigraphic, crystalline and mechanical structure. CRREL Rep. 77-1.

Hattersley-Smith, G. 1957. The rolls on the Ellesmere Ice Shelf. Arctic, 10(1), 32-44.

Hattersley-Smith, G. and H. Serson. 1970. Mass balance of the Ward Hunt ice rise and Ice Shelf: a 10 year record. F. Glaciol., 9(56), 247-252.

Hobson, G. and 18 others. 1989. Ice island field station: new features of Canadian Polar Margin. EOS, 70(37), 833, 838-839.

Jeffries, M.O. 1985. Physical, chemical and isotopic investigations of Ward Hunt Ice Shelf and Milne Ice Shelf, Ellesmere Island, N.W.T. (Ph.D. thesis, University of Calgary.)

Jeffries, M.O. 1987. The growth, structure and disintegration of Arctic ice shelves. Polar Rec., 23(147), 631649.

Jeffries, M. O. 1991. Massive, ancient sea-ice strata and preserved physical-structural characteristics in the Ward Hunt Ice Shelf. Ann. Glaciol., 15, 125-131.

Jeffries, M. O. In press. Perennial water stratification and the role of basal freshwater flow in the mass balance of the Ward Hunt Ice Shelf, Canadian High Arctic. In Proceedings of the International Conference on the Role of the Polar Regions in Global Change, 11-15 June 1990, University of Alaska Fairbanks, Fairbanks, Alaska, U.S.A.

Jeffries, M. O. and H.R. Krouse. 1987. Snowfall and oxygen-isotope variations off the north coast of Ellesmere Island, N.W.T., Canada. F. Glaciol., 33(114), 195-199.

Jeffries, M. O. and W. M. Sackinger. 1989. Some measurements and observations of very old sea ice and brackish ice, Ward Hunt Ice Shelf, N.W.T. AtmosphereOcean, 27(3), 553-564.

Jeffries, M. O. and H. Serson. 1983. Recent changes at the front of Ward Hunt Ice Shelf, Ellesmere Island, N.W.T. Arctic, 36(3), 289-290.

Jeffries, M. O., W. M. Sackinger, H. R. Krouse and H. V. 
Serson. 1988. Water circulation and ice accretion beneath Ward Hunt Ice Shelf (northern Ellesmere Island, Canada) deduced from salinity and isotope analysis of ice cores. Ann. Glaciol., 10, 68-72.

Jeffries, M. O., N. K. Sinha and W. M. Sackinger. 1990a. Deformation of natural ice island ice under constant strain rate uniaxial compression. In IAHR. The 10th International Symposium on Ice. Proceedings. Vol. 1. Espoo, Helsinki University of Technology, 238-251.

Jeffries, M. O., N. K. Sinha and W. M. Sackinger. 1990b. Failure stress and failure modulus of natural ice island ice under uniaxial compression at constant strain rates. In Ayorinde, O. A., N. K. Sinha and D. S. Sodhi, eds. Proceedings of the Ninth International Conference on Offshore Mechanics and Arctic Engineering - 1990 - presented at Houston, Texas, February 18-23, 1990. Volume 4. Arctic/polar technology. New York, American Society of Mechanical Engineers, 223-229.

Keys, J.E. 1978. Water regime of Disraeli Fiord, Ellesmere Island. Ottawa, Defence Research Establishment Ottawa. (DREO Report 792.)

Koenig, L.S., K.R. Greenaway, M. Dunbar and G. Hattersley-Smith. 1952. Arctic ice islands. Arctic, 5(2), 67-103.

Koerner, R. M. 1968. Fabric analysis of a core from the Meighen Ice Cap, Northwest Territories, Canada. F. Glaciol., 7(51), 421-430.

Koerner, R. M. 1970. Some observations on superimposition of ice on the Devon Island ice cap, N.W.T. Canada. Geogr. Ann., 52A(1), 57-67.

Koerner, R. M. and W. S. B. Paterson. 1974. Analysis of a core through the Meighen Ice Cap, Arctic Canada, and its paleoclimatic implications. Quat. Res., 4(3), 253-263.

Koerner, R.M., W.S.B. Paterson and H.R. Krouse. 1973. $\delta^{18} \mathrm{O}$ profile in ice formed between the equilibrium and firn lines. Nature, 245(148), 137-140.

Lemmen, D.S., D.J.A. Evans and J. England. 1988a. Discussion of "Glaciers and the morphology and structure of the Milne Ice Shelf, Ellesmere Island, N.W.T., Canada" by Martin O. Jeffries. Arct. Alp. Res., 20(3), 366-368.

Lemmen, D. S., D. J. A. Evans and J. England. 1988b. Ice shelves of northern Ellesmere Island, NWT. Can. Geogr., 32(4), 363-367.

Lister, H. 1962. Mass balance studies on the Ellesmere Ice Shelf. 7. Glaciol., 4(33), 298-299.

Lyons, J. B. and J. E. Mielke. 1973. Holocene history of a portion of northernmost Ellesmere Island. Arctic, 26(4), 314-323.

Lyons, J.B., S. M. Savin and A.J. Tamburi. 1971. Basement ice, Ward Hunt Ice Shelf, Ellesmere Island, Canada. 7. Glaciol., 10(58), 93-100.

Marshall, E. W. 1955. Structural and stratigraphic studies of the northern Ellesmere Ice Shelf. Arctic, 8(2), 109114.

Marshall, E.W. 1960. Structure and stratigraphy of T-3 and the Ellesmere Ice Shelf. In Bushnell, V., ed. Scientific studies at Fletcher's Ice Island, T-3, 1952-55. Vol. III. Bedford, MA, Air Force Cambridge Research Center, 45-57. (Geophysical Research Paper 63.)

Muguruma, J. and K. Higuchi. 1963. Glaciological studies on ice island T-3. F. Glaciol., 4(36), 709-730.

Narod, B. B., G. K. C. Clarke and B. T. Prager. 1988.
Airborne radar sounding of glaciers and ice shelves, northern Ellesmere Island, Canada. Can. 7. Earth Sci., 25(1), 95-105.

Ragle, R. H., R. G. Blair and L. E. Persson. 1964. Ice core studies of Ward Hunt Ice Shelf. J. Glaciol., 5(37), 39-59.

Serson, H. 1979. Mass balance of the Ward Hunt ice rise and Ice Shelf: an 18-year record. Victoria, B.C., Defence Research Establishment Pacific. (DREP Technical Memorandum 79-4.)

Smith, D. D. 1961. Sequential development of surface morphology on Fletcher's Ice Island, T-3. In Raasch, G. O., ed. Geology of the Arctic. Vol. 2. Toronto, University of Toronto Press, 896-914.

Smith, D.D. 1964. Ice lithologies and structure of ice island ARLIS-II. J. Glaciol., 5(37), 17-38.

The accuracy of references in the text and in this list is the responsibility of the authors, to whom queries should be addressed.

\section{APPENDIX A}

\section{ONE-WAY ANALYSIS OF VARIANCE OF SUB- STRATA $\delta^{18} O$ VARIATIONS WITHIN CORES}

Table A-I. Results of a one-way ANOVA of the variation of $\delta^{18} \mathrm{O}$ values in core $85-10$

\begin{tabular}{lrrrrrr} 
Source & $\begin{array}{c}\text { Degrees of } \\
\text { freedom }\end{array}$ & $\begin{array}{c}\text { Sum of } \\
\text { squares }\end{array}$ & $\begin{array}{c}\text { Mean } \\
\text { square }\end{array}$ & F-ratio & Probability \\
\hline & & & & & & \\
Strata & 2 & 48.559 & 24.2795 & 7.63 & 0.0008 \\
Error & 106 & 337.487 & 3.18384 & & \\
Total & 108 & 386.046 & & &
\end{tabular}

Table A-II. Results of a one-way ANOVA of the variation of $\delta^{18} O$ values in core $86-1$

\begin{tabular}{|c|c|c|c|c|}
\hline Source & $\begin{array}{c}\text { Degrees of } \\
\text { freedom }\end{array}$ & $\begin{array}{l}\text { Sum of } \\
\text { squares }\end{array}$ & $\begin{array}{l}\text { Mean } \\
\text { square }\end{array}$ & F-ratio Probability \\
\hline
\end{tabular}

$\begin{array}{lrcccc}\text { Strata } & 2 & 46.7705 & 23.3852 & 8.64 & 0.0005 \\ \text { Error } & 61 & 165.189 & 2.70801 & & \\ \text { Total } & 63 & 211.959 & & & \end{array}$


Table A-III. Results of a one-way ANOVA of the variation of $\delta^{18} O$ values in core $86-2$

\begin{tabular}{lrrrrr} 
Source & $\begin{array}{c}\text { Degrees of } \\
\text { freedom }\end{array}$ & $\begin{array}{l}\text { Sum of } \\
\text { squares }\end{array}$ & $\begin{array}{l}\text { Mean } \\
\text { square }\end{array}$ & F-ratio & Probability \\
\hline Strata & 2 & 13.947 & 6.9735 & 1.86 & 0.1704 \\
Error & 34 & 127.146 & 3.73959 & & \\
Total & 36 & 141.093 & & & \\
& & & & &
\end{tabular}

Table A-IV. Results of a one-way ANOVA of the variation of $\delta^{18} O$ values in core $87-1$

\begin{tabular}{lrcccc} 
Source & $\begin{array}{c}\text { Degrees of } \\
\text { freedom }\end{array}$ & $\begin{array}{c}\text { Sum of } \\
\text { squares }\end{array}$ & $\begin{array}{c}\text { Mean } \\
\text { square }\end{array}$ & F-ratio & Probability \\
\hline Strata & 2 & 68.3789 & 34.1895 & 17.00 & 0.0000 \\
$\begin{array}{l}\text { Error } \\
\text { Total }\end{array}$ & 61 & 122.467 & 2.00766 & & \\
& 63 & 190.846 & & &
\end{tabular}

\section{APPENDIX B}

ONE-WAY ANALYSIS OF VARIANCE OF SUBSTRATA $\delta^{18} O$ VARIATIONS BETWEEN CORES

Table B-I. Results of a one-way ANOVA of the variation of $\delta^{18} O$ values in stratum $A-I$

\begin{tabular}{lrrrrr} 
Source & $\begin{array}{c}\text { Degrees of } \\
\text { freedom }\end{array}$ & $\begin{array}{c}\text { Sum of } \\
\text { squares }\end{array}$ & $\begin{array}{l}\text { Mean } \\
\text { square }\end{array}$ & F-ratio & Probability \\
\hline Core & 3 & 3.56515 & 1.8838 & 0.395 & 0.757 \\
Error & 82 & 246.764 & 3.00932 & & \\
Total & 85 & 250.329 & & &
\end{tabular}

Table B-II. Results of a one-way ANOVA of the variation of $\delta^{18} O$ values in stratum $A-I I$

\begin{tabular}{lrlllll} 
Source & $\begin{array}{c}\text { Degrees of } \\
\text { freedom }\end{array}$ & $\begin{array}{c}\text { Sum of } \\
\text { squares }\end{array}$ & $\begin{array}{c}\text { Mean } \\
\text { square }\end{array}$ & F-ratio & Probability \\
\hline & & & & & \\
Core & 3 & 6.57801 & 2.19267 & 0.812 & 0.4893 \\
Error & 148 & 399.844 & 2.70165 & & \\
Total & 151 & 406.422 & & & \\
\hline
\end{tabular}

Table B-III. Results of a one-way ANOVA of the variation of $\delta^{18} O$ values in stratum $A-I I I$

\begin{tabular}{lrlllll} 
Source & $\begin{array}{c}\text { Degrees of } \\
\text { freedom }\end{array}$ & $\begin{array}{c}\text { Sum of } \\
\text { squares }\end{array}$ & $\begin{array}{c}\text { Mean } \\
\text { square }\end{array}$ & F-ratio Probability \\
\hline Core & 3 & 0.582222 & 0.194074 & 0.059 & 0.981 \\
Error & 32 & 105.681 & 3.30253 & & \\
Total & 34 & 106.263 & & & \\
\hline
\end{tabular}

\section{APPENDIX G}

TWO-WAY ANALYSIS OF VARIANCE OF WITHINCORE AND BETWEEN-CORE $\delta^{18} O$ VARIATIONS IN SUB-STRATA A-I, A-II AND A-III

Table C-I. Results of a two-way ANOVA

\begin{tabular}{lrccccc} 
Source & $\begin{array}{c}\text { Degrees of } \\
\text { freedom }\end{array}$ & $\begin{array}{c}\text { Sum of } \\
\text { squares }\end{array}$ & $\begin{array}{c}\text { Mean } \\
\text { square }\end{array}$ & F-ratio & Probability \\
\hline Stratum & 2 & 143.329 & 71.6644 & 25.0 & 0.0000 \\
Core & 3 & 0.224984 & 0.074995 & 0.026 & 0.9943 \\
Interaction & 6 & 8.85276 & 1.47546 & 0.514 & 0.7977 \\
Error & 262 & 752.289 & 2.87133 & & \\
Total & 273 & 934.934 & & & \\
\hline
\end{tabular}

